\title{
Histological alterations in liver and testis of Astyanax aff. bimaculatus caused by acute exposition to zinc ${ }^{1}$
}

\author{
Daiane Cristina Marques dos Santos*2, Marli do Carmo Cupertino ${ }^{3}$, Sérgio Luis Pinto da Matta ${ }^{4}$, \\ Juraci Alves de Oliveira ${ }^{5}$, Jorge Abdala Dergam dos Santos 6 \\ http://dx.doi.org/10.1590/0034-737X201562020002
}

\begin{abstract}
This study investigated the effect of acute exposition to zinc ( $\mathrm{Zn}$ ) on histology of the liver and testes of yellow tail lambari (Astyanax aff. bimaculatus). The exposure consisted of six concentrations of $\mathrm{Zn}(0,3,5,10$, 15, and $20 \mathrm{mg} / \mathrm{L}$ ) for 96 hours of exposure. Fragments of liver and testis were routinely processed and embedded in plastic resin based on glycol methacrylate. Fragments of bones, muscles, liver and testis were dehydrated and digested to quantify the absorption levels of $\mathrm{Zn}$ in the tissue. Acute exposure to concentrations above $10 \mathrm{mg} / \mathrm{L}$ has produced structural changes in the liver and gonads. The changes found in the liver were vascular congestion; decrease of cellular volume; displacement of the hepatocyte nucleus; necrosis; disarrangement of cordon structure; leukocyte infiltrate and vacuolization. The changes found in the gonads were ruptured cyst, delayed development of germ cells, pyknotic nucleus, cell cluster, displacement of cyst wall and vacuolization. The histological changes observed were compatible with the increasing concentration of zinc in environment, compromising liver and reproductive functions, because there was an increase in relative frequency of hepatocytes and reduced sperm production.
\end{abstract}

Key words: aquatic contamination, gonad, heavy metal, histopathology, liver, yellow tail lambari.

\section{RESUMO}

\section{Alterações histológicas em fígado e testículos de Astyanax aff. bimaculatus causadas pela exposição aguda ao zinco}

Este estudo investigou o efeito da exposição aguda do zinco (Zn) na histologia do fígado e testículos de lambari do rabo-amarelo (Astyanax aff. Bimaculatus). A exposição consistiu de seis concentrações de Zn, 0, 3, 5, 10, 15 e $20 \mathrm{mg} / \mathrm{L}$ por 96 horas de exposição. Fragmentos de fígado e testículos foram processados rotineiramente para inclusão em resina plástica a base de glicol metacrilato. Fragmentos de ossos, músculos, fígado e testículos foram desidratados e digeridos para quantificar os níveis teciduais da absorção de Zn. A exposição aguda a concentrações de acima de $10 \mathrm{mg} / \mathrm{L}$ produziu alterações estruturais no fígado e gônada. As alterações encontradas no fígado foram: congestão vascular, diminuição do volume celular; deslocamento do núcleo dos hepatócitos, necrose; desarranjo na estrutura do cordonal; infiltrado leucocitário e vacuolização. As alterações encontradas nas gônadas foram ruptura de cisto, retardo no desenvolvimento das células da linhagem germinativa, núcleo picnótico, aglomerado de celular, deslocamento da parede do cisto e vacuolização. As alterações histológicas observadas foram compatíveis

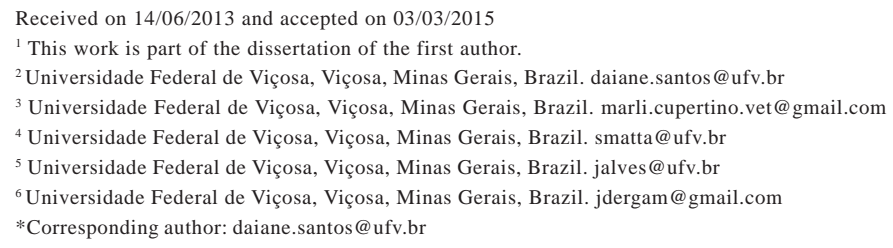


com o aumento da concentração de Zn no ambiente, comprometendo as funções hepáticas e reprodutivas, devido ao aumento no número de hepatócitos e redução na produção de espermatozoides.

Palavras-chave: metal pesado, contaminação aquática, lambari do rabo amarelo, gônadas, fígado, histopatologia.

\section{INTRODUCTION}

There is a large amount of pollutants affecting the aquatic environment, whose effects are toxic to most tissues. The study of the effects of pollutants on freshwater fish becomes essential for controlling the environmental pollution (Martinez \& Cólus, 2002). Heavy metals are among the major classes of contaminants that are often found in these ecosystems (Oliveira Ribeiro et al., 2005; Nigro et al., 2006; Munteanu \& Munteanu 2007).

Zinc is classified as a micronutrient and required to perform cellular function (McGeer et al,. 2000). However, in high concentrations, it can become especially toxic to fish and other aquatic organisms (Romani et al., 2003; Celik \& Oehlenschager, 2004).

Histopathological lesions have often been described as important tools in biomonitoring studies due to ease of interpretation, both in situations of acute and chronic exposure (Wester et al., 2002; Gül et al., 2004; Oliveira Ribeiro et al., 2005; Santos et al., 2012). In studies on the action of chemical pollutants on fish, the liver is regarded a key organ. It is the first organ to act in the biotransformation of xenobiotics and probably also in the excretion of metals (Gül et al., 2004).

Areas of necrosis, nuclear damage and cellular death were reported by Rabitto et al. (2005) in Hoplias malabaricus (trahiras), after chronic exposure to lead. Oliveira Ribeiro et al. (2002) found cytoplasmic disorganization and areas of necrosis after trophic exposure to methylmercury.

Severe morphological changes occurring during gonadal differentiation were diagnosed in Pimephales promelas (fathead minnow), Brachydanio rerio (zebrafish) and Poecilia reticulata (guppy), when contaminated with sublethal concentrations of copper (Rand \& Petrocelli 1985). In Oreochromis niloticus (Nile tilapia) exposed to acute concentrations of endosulfan, a reduced population of germ cells was found (Montoya, 2008).

In this context, it was proposed to study the effects of acute exposure to $\mathrm{Zn}$ in adults of Astyanax. aff. Bimaculatus (yellow tail lambari) on liver and testis, through morphometric and morphological analyses.

\section{MATERIALAND METHODS}

This study was approved by the Veterinary Ethics Committee of the Federal University of Viçosa, protocol 36/2008. Seventy-two A. aff. bimaculatus males were randomly collected 70 days after spawning, at Piscicultura do Prata, Eugenópolis, Minas Gerais State, Brazil, in the basin of Paraíba do Sul River. The treatments consisted of six concentrations of zinc $(0,3,5,10,15$, and $20 \mathrm{mg} / \mathrm{L}$ ), available as $\mathrm{ZnSO}_{4} \cdot 7 \mathrm{H}_{2} \mathrm{O}$, for 96 hours of exposure.

During the adaptation period, glass tanks were used, with a capacity of $150 \mathrm{~L}$ of water, chlorine-free, keeping 12 fish per aquarium for 40 days. All aquariums had filtration system by gravel of different sizes and an acrylic mesh, with filtration system with pumps and continuous water aeration. The dissolved oxygen, toxic ammonia, total hardness and nitrite, $\mathrm{pH}$ and electrical conductivity were measured once, every 24 hours. The temperature was controlled $\left(26 \pm 1^{\circ} \mathrm{C}\right)$ (Fishbase 2013) through heaters and thermostats. The photoperiod was set at 12 hours-dark/12 hours-light, controlled by timer. The fish were daily fed "ad libitum" with commercial feed offered three times a day.

After the exposure to different concentrations of zinc, experimental data were collected every hour. The animals that died in this interval were removed from the aquarium and submitted to the same procedures of those that survived until the end of the exposure time, except for euthanasia. At the end of exposure, the animals were previously anesthetized with benzocaine solution of $1: 10.000$, which was followed by the deepening of the anesthesia application, until they were euthanized (Ross \& Ross, 2000). All animals were weighed, measured, and the tissues collected for analysis of $\mathrm{Zn}$ concentration, processing and histological analysis.

\section{Determination of Zn concentration in tissues}

Samples of bones, testis, liver and muscles were incubated at $70{ }^{\circ} \mathrm{C}$, after weighing, until they reached constant dry weight. It was added in the samples, $1.5 \mathrm{~mL}$ of concentrated $\mathrm{HNO}_{3}, 0.5 \mathrm{~mL}$ of $\mathrm{HClO}_{4}(70 \%)$ and 2 drops of hydrogen peroxide (30\%). The samples were carried to the digester block and the temperature was gradually 
increased, from $70{ }^{\circ} \mathrm{C}$ to $90{ }^{\circ} \mathrm{C}$, so that the complete digestion lasted about 30 minutes. After dilution of the digested material, $\mathrm{Zn}$ concentrations were determined by atomic absorption spectrophotometry (Shimadzu AA 6701).

The results obtained in each organ were submitted to the analysis of variance and the means were compared by the Tukey's test at $5 \%$ of probability.

\section{Analyses of liver and testis}

Fragments of the liver and testis median region were removed and fixed in Karnovsky solution for 24 hours. After that, they were placed in increasing ethanol series, and embedded in glycol methacrylate. After inclusion, serial sections were performed in the testis, and semi-serial sections, in the liver, both with thickness of $3 \mu \mathrm{m}$, in rotary microtome. Liver preparations were stained with Mayer's hematoxylin and phloxine B, and the testis, with toluidine blue and sodium borate $1 \%$, and digital images were obtained through photomicroscope (Olympus AX70 TRF).

The images of the liver were morphometrically analyzed by counting the points (intersections) on the nucleus and cytoplasm of hepatocytes, sinusoidal capillary and leukocyte infiltrate, totaling 3200 points/ animal. These analyses were performed by grid with 800 intersections of the Image Pro Plus software system. It also measured the diameter of 30 nuclei of hepatocytes per treatment. The results were submitted to the analysis of variance, and the means were compared by the Tukey's test at $5 \%$ of probability.

For the histological analyses of liver, the following pathologies were qualified and quantified: vascular congestion, decreased cellular volume, displacement of the hepatocyte nucleus, necrosis, disarrangement of cordonal structure, leukocyte infiltrate and vacuolization. If the pathology was present in at least one of the fields displayed, it would be considered present in the animal. In the end, a relationship was made between the animals with the pathology and the total treatment $(n=12)$, expressing the result as a percentage.

The images of the testis were morphologically and morphometrically analyzed according to Matta et al. (2002). Morphometrically, four fields of ratio were analyzed between the tubule and intertubule, and testicular fluid and sperm per animal, with a total of 2000 points/animal. These analyses were performed by grid with 500 intersections of the Image Pro Plus software system.

For histological analyses of the testis, the following pathologies were qualified and quantified: ruptured cyst, delayed development of cysts, cells with pyknotic nucleus, cell cluster, detachment of tubules wall and vacuolization of germinal epithelium, using ten fields/ animal. If the pathology was present in at least one of the fields displayed, it would be considered present in the animal. In the end, a relationship was established between the animals with the pathology and the total treatment $(n=12)$, and the result was expressed as a percentage.

\section{RESULTS AND DISCUSSION}

In the control treatments, and where $\mathrm{Zn}$ concentrations were 3 and $5 \mathrm{mg} / \mathrm{L}$, no mortality of fish was found by the end of the exposure period. In the treatment where zinc concentration was $10 \mathrm{mg} / \mathrm{L}$, fish mortality reached $50 \%$ after 24 hours of exposure, without any more deaths up to the end of 96 hours. In the treatment that received $15 \mathrm{mg} / \mathrm{L}$, after $24 \mathrm{~h}$ of exposure, $67 \%$ of fish died, and after 72 hours of exposure, $75 \%$ died, indicating the high level of toxicity of $\mathrm{Zn}$ for the species under study. Within 24 hours of exposure, the treatment that received $20 \mathrm{mg} / \mathrm{L}$ presented $100 \%$ of mortality.

Fish submitted to concentrations of 10, 15 and 20 $\mathrm{mg} / \mathrm{L}$, fish that died and those that remained alive at the end of 96 hours of exposure showed abnormal behavior, staying near the surface of the aquarium, with intense opercular beat, uncoordinated swimming and lethargy. On the other hand, animals that did not receive $\mathrm{Zn}$ or those receiving the metal at concentrations of 3 or 5 $\mathrm{mg} / \mathrm{L}$, moved up strongly in the pods and fed normally, presenting a typical behavior of the species.

Exposure of animals to $10 \mathrm{mg} / \mathrm{L}$ of $\mathrm{Zn}$ has produced deposition of this metal in the bone fragment, followed by liver and testis. There was no significant accumulation in the muscle tissue (Table 1).

In the liver, accumulation of $\mathrm{Zn}$ was found in the animals treated with $10 \mathrm{mg} / \mathrm{L}$, especially those that remained alive until the end of the experiment. Only animals in concentrations of $10 \mathrm{mg} / \mathrm{L}$ presented metal accumulation in the liver, and both exposure, with lower and higher concentrations, presented no accumulation. The possible explanation could be the ability of fish to metabolize and excrete xenobiotics, and, at these dosages, a toxic concentration was not reached. In exposure with doses above $10 \mathrm{mg} / \mathrm{L}$, there was a rapid mortality of fish, without enough time for accumulation in tissues. Nevertheless, there were changes in the organ morphology, even in the absence of metal accumulation (Table 1).

In treatments where fish were not exposed to $\mathrm{Zn}$, and in solutions of 3 to $5 \mathrm{mg} / \mathrm{L}$, no significant accumulation was observed in bones, probably because of the essential trace element for animal nutrition. Thus, at lower 
concentrations, it was metabolized or excreted, not characterizing toxicity to fish. Only in exposures with higher concentrations (10, 15 and $20 \mathrm{mg} / \mathrm{L})$, significant accumulation in bone tissue was found (Table 1).

Papagiannis et al. (2004) collected four species of fish from Lake Pamvotis (Greece), and analyzed the concentrations of copper and zinc in the liver, muscles and gonads. These tissues showed significant concentrations of metals, and the liver showed the highest accumulation, followed by gonads and muscle. This difference can be due to the exposure manner. Here, the animals were submitted to acute exposure, while the animals from lake Pamvotis were submitted to the chronic action of this metal.

Hogstrand \& Wood (1995) showed that one of the most important sublethal effects of $\mathrm{Zn}^{2+}$ in fish is the inhibition of calcium absorption $\left(\mathrm{Ca}^{2+}\right)$, since zinc competes for the same absorption sites in the gills. Consequently, the excess can lead to hypocalcaemia. Therefore, reducing the concentration of $\mathrm{Ca}^{2+}$ would be harmful to the organism, since this element is essential for the integrity of the cell membrane (De La Torre et al., 2000).

The concentration of $\mathrm{Zn}$ determined in the testes was similar for the control treatments and for the concentrations of 3, 5, 15 and $20 \mathrm{mg} / \mathrm{L}$. However, in the concentration of $10 \mathrm{mg} / \mathrm{L}$, in which $\mathrm{CL}_{50}$ was estimated, there was no statistical difference compared to control. Probably, similarly to the exposure of 15 and $20 \mathrm{mg} / \mathrm{L}$, there was, respectively, 75 and $100 \%$ mortality of the fish in a relatively short time (about 24h), without sufficient time for the fish to be in contact with the metal for accumulation in this organ. On the other hand, lower doses were not sufficient to promote the accumulation in the gonads. However, in the treatment of $10 \mathrm{mg} / \mathrm{L}$, as there was $50 \%$ mortality of fish and the others remained for a longer period $(96 \mathrm{~h})$ in contact with $\mathrm{Zn}$, in relatively high concentration, there was a greater accumulation (Table 1).

Regarding histology, the liver of $A$. aff. bimaculatus is characterized by a cordon distribution of hepatocytes, and the sinusoids are irregularly distributed among the liver cells, being coated by endothelial cells. Hepatocytes presented a clear cytoplasm with one or two central nuclei and a round shape, and in some regions, it was displaced to the periphery of the cell (Figure 1). These morphological descriptions are consistent with those of Souza et al. (2001) and Fujimoto et al. (2008) for pacu (Piaractus mesopotamicus).

The histopathological changes found were as follows: vascular congestion, reduced cellular volume, displacement of the hepatocyte nucleus, necrosis, disarrangement of cordon structure, leukocyte infiltrate and vacuolization (Table 2; Figure 1).

In fish exposed to 3 and $5 \mathrm{mg} / \mathrm{L}$, similar disarrangements of cord structures of hepatocytes were found. In treatments with higher concentrations, this pathology was $70 \%$ (Table 3; Figure 1). These changes can indicate the initial degeneration of intracellular processes of hepatocytes, since the liver plays an important role in the detoxification process of the animal (Dutta et al., 1993).

Hepatic vascular congestion was found in fish from treatment with $3 \mathrm{mg} / \mathrm{L}$ of $\mathrm{Zn}$, with a progressive increase, reaching $100 \%$ in treatments with concentrations superior to $10 \mathrm{mg} / \mathrm{L}$ (Table 3; Figure 1, B, C, D, E and F). According to Verlag (1982), hepatic cells in the adjacent area can suffer atrophy in severe cases of congestion. This change is defined as the accumulation of blood causing dilation of blood vessels. This circulatory disturbance is related to the decrease in the velocity of blood flow in the site. In major causes, it triggers a decrease in the metabolic exchanges between blood plasma and tissue, causing damage to local cells (Roberts, 1989).

Gül et al. (2004), when investigating the hepatic histopathology in freshwater fish from polluted areas, observed vascular congestions as well as micro and macro-vesicular fatty degeneration.

In the treatment where fish were not exposed to $\mathrm{Zn}$, and at $3 \mathrm{mg} / \mathrm{L}$, no areas with necrosis were identified. However, in the exposure to 10,15 and $20 \mathrm{mg} / \mathrm{L}$, necrosis of the liver tissue was found in $50 \%$ or more animals (Table 3; Figure 1). Necrosis can be characterized by

Table 1.Zinc concentration in tissues (muscle, bone, liver and testis) of Astyanax aff. bimaculatus submitted to different concentrations of zinc

\begin{tabular}{lcccc}
\hline Treatment & Muscle & Bone & Testis & Liver \\
\hline 0.0 & $0.0287^{\mathrm{a}}$ & $0.0490^{\mathrm{a}}$ & $0.0370^{\mathrm{ab}}$ & $0.0646^{\mathrm{a}}$ \\
3.0 & $0.0249^{\mathrm{a}}$ & $0.0491^{\mathrm{a}}$ & $0.0541^{\mathrm{ab}}$ & $0.0554^{\mathrm{ab}}$ \\
5.0 & $0.0324^{\mathrm{a}}$ & $0.0647^{\mathrm{ab}}$ & $0.0535^{\mathrm{a}}$ & $0.0464^{\mathrm{ab}}$ \\
10.0 & $0.0235^{\mathrm{a}}$ & $0.0721^{\mathrm{bc}}$ & $0.0593^{\mathrm{b}}$ & $0.0715^{\mathrm{b}}$ \\
15.0 & $0.0249^{\mathrm{a}}$ & $0.0765^{\mathrm{bc}}$ & $0.0508^{\mathrm{ab}}$ & $0.0507^{\mathrm{ab}}$ \\
20.0 & $0.0279^{\mathrm{a}}$ & $0.0856^{\mathrm{c}}$ & $0.0522^{\mathrm{ab}}$ & $0.0499^{\mathrm{ab}}$ \\
\hline
\end{tabular}

* Means with the same letter do not differ significantly per treatment $(\mathrm{p}>0.05)$. 
nuclear and cytoplasmatic changes, followed by loss of cell boundaries. When necrosis occurs in a cell, signalizers are released, which induce cell proliferation to replace the dead cells and recover a structural and functional tissue condition (Roberts, 1989). This type of lesion causes functional and structural losses in the liver of fish (Stentiford et al., 2003), decreasing the functionality. It can cause organ failure and consequently affect higher levels of the biological organization (Rabitto et al., 2005). Necrosis may also indicate degeneration of structural proteins in the membrane of hepatocytes, and can cause tissue problems, because, according to Pacheco \& Santos (2002), these proteins keep the hepatic parenchyma as a compact and homogeneous tissue.

There was a progressive increase in the percentage of nuclei of hepatocytes accompanied by a reduction in the percentage of cytoplasm, indicating an increase in the liver cell population (Table 3). The increasing area occupied by sinusoidal capillaries and leukocyte infiltrate, although being light, but constant, confirms the toxicity of $\mathrm{Zn}$. Leukocyte infiltrate was also found by Rodrigues \& Fanta (1998), when studying the action of organophosphate in zebrafish (B. rerio). Santos et al. (2004) found that liver tissues of Nile Tilapia $(O$. niloticus) collected in the reservoir of Guarapiranga, State of São Paulo, Brazil, presented hepatocytes with pyknotic core, progressing to a condition of karyolysis, dense granules in the cytoplasm and foci of degeneration, leukocytes within sinusoids, marginal vessels and infiltrates, suggesting the occurrence of an inflammatory process (Table 2).

A decrease in the nuclear diameter of hepatocytes in relation to the increase of concentration was found. In the treatment that used the highest concentration of $\mathrm{Zn}$, there was a rapid mortality of fish ( 24 hours), and even in this short time of exposure, the animals presented greater reduction in the nuclear diameter of hepatocytes (Table 2). This result is likely to be related to the mechanisms that regulate the multiplication of hepatocytes and to a higher incidence of necrosis leading to cellular death and inducing the increase in hepatocyte proliferation for cell replacement of damaged tissue. Extensive proliferation of hepatocytes was found in the investigation of hepatic histopathology in freshwater fish from polluted areas (Gül et al,. 2004).

In relation to histology, the testes of $A$. aff. Bimaculatus exhibit characteristics similar to other teleost, showing a generally tubular cystic seminiferous tubular organization. The changes evidenced in the gonads exposed to concentrations of $\mathrm{Zn}$ were as follows: ruptured cyst, delayed development of germ cells, pyknotic nucleus, cell cluster, detachment of the cyst wall and vacuolization (Figure 2; Table 4).

Zinc negatively affected the development of germ cells, causing a delay in the development of cysts (Figu-

Table 2. Pathological alteration percentage detected in the liver of Astyanax aff. bimaculatus submitted to different concentrations of zinc

\begin{tabular}{|c|c|c|c|c|c|c|c|}
\hline \multirow{2}{*}{$\begin{array}{l}\text { Zn concentration } \\
(\mathrm{mg} / \mathrm{L})\end{array}$} & \multicolumn{7}{|c|}{ Liver histopathology (\%) } \\
\hline & $\mathbf{V C}$ & DV & DN & $\mathrm{Ne}$ & DS & $\mathbf{L I}$ & Va \\
\hline 0 & 0.0 & 0.0 & 0.0 & 0.0 & 0.0 & 0.0 & 0.0 \\
\hline 3 & 41.7 & 100.0 & 33.3 & 0.0 & 41.7 & 41.7 & 16.7 \\
\hline 5 & 66.6 & 100.0 & 100.0 & 8.3 & 50.0 & 83.3 & 25.0 \\
\hline 10 & 100.0 & 100.0 & 100.0 & 50.0 & 70.0 & 83.3 & 66.7 \\
\hline 15 & 100.0 & 100.0 & 100.0 & 50.0 & 70.0 & 100.0 & 41.7 \\
\hline 20 & 100.0 & 100.0 & 100.0 & 58.3 & 70.0 & 100.0 & 75.0 \\
\hline
\end{tabular}

$\mathrm{VC}=$ Vascular congestion; $\mathrm{DV}=$ Decreased cell volume; $\mathrm{DN}=$ Displacement of the hepatocyte nucleus; $\mathrm{Ne}=\mathrm{Necrosis} ; \mathrm{DS}=$ Disarrangement of cordon structure; $\mathrm{LI}=$ Leukocyte infiltrate; $\mathrm{Va}=$ Vacuolization.

Table 3. Tissue constitution percentage and nuclear diameter of hepatocytes in the liver of Astyanax aff. bimaculatus submitted to different concentrations of zinc

\begin{tabular}{lccccc}
\hline \multirow{2}{Z}{$\begin{array}{l}\text { Zn concentration } \\
(\mathbf{m g} / \mathbf{L})\end{array}$} & Nucleus & Cytoplasm & $\begin{array}{l}\text { Sinusoid } \\
\text { capillary }\end{array}$ & $\begin{array}{r}\text { Leukocyte } \\
\text { Infiltration }\end{array}$ & $\begin{array}{c}\text { Nuclear diameter of } \\
\text { hepatocytes }(\mu \mathrm{m})\end{array}$ \\
\cline { 2 - 6 } & & 76.7 & 12.3 & 0.1 & $5.50^{\mathrm{a}}$ \\
\hline 0 & 10.8 & 72.6 & 14.7 & 0.2 & $5.06^{\mathrm{b}}$ \\
3 & 12.4 & 65.7 & 19.6 & 0.6 & $4.84^{\mathrm{bc}}$ \\
5 & 14.0 & 55.3 & 26.2 & 0.7 & $4.76^{\mathrm{bc}}$ \\
10 & 17.7 & 46.3 & 29.1 & 1.7 & $4.81^{\mathrm{bc}}$ \\
15 & 22.7 & 48.3 & 28.9 & 1.8 & $4.66^{\mathrm{c}}$ \\
\hline
\end{tabular}



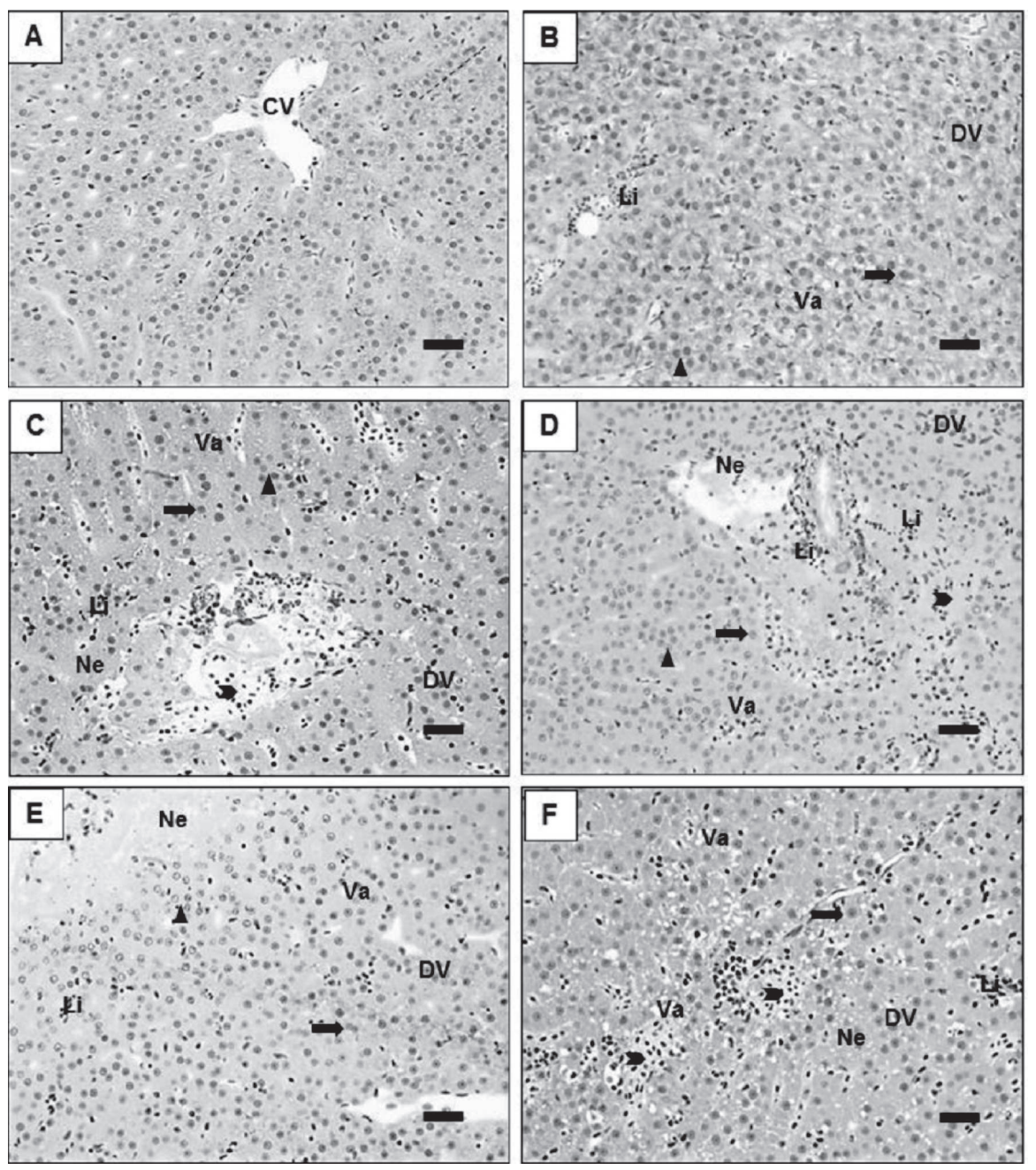

Figure 1. Liver of Astyanax aff. bimaculatus exposed to different concentrations of zinc. A) Control group. B) $3 \mathrm{mg} / \mathrm{L}$. C) $5 \mathrm{mg} / \mathrm{L}$. D) $10 \mathrm{mg} / \mathrm{L}$. E) $15 \mathrm{mg} / \mathrm{L}$. F) $20 \mathrm{mg} / \mathrm{L}$. Bar: $20 \mu \mathrm{m}$. Cordon structure= dashed line; Central vein= CV; Vascular congestion= motto; Decreased cell volume $=\mathrm{DV}$; Displacement of the hepatocyte nucleus $=$ full arrow; Necrosis $=\mathrm{Ne}$; Disarrangement of cordon structure $=$ arrowhead; Leukocyte infiltrate $=\mathrm{Li}$; Vacuolization $=$ Va.

Table 4. Pathological alterations percentage in testes of Astyanax aff. bimaculatus submitted to different concentrations of zinc

\begin{tabular}{lrrrrrr}
\hline Zn concentration & \multicolumn{5}{c}{ Testicular histopathology (\%) } \\
\cline { 2 - 7 }$(\mathbf{m g} / \mathbf{L})$ & $\mathbf{R C}$ & DD & PN & CC & \multicolumn{1}{c}{ DC } & Va \\
\cline { 2 - 7 } 0 & 16.7 & 0.0 & 8.3 & 8.3 & 0.0 & 8.3 \\
3 & 83.3 & 83.3 & 91.7 & 66.7 & 8.3 & 33.3 \\
5 & 91.7 & 100.0 & 100.0 & 100.0 & 25.0 & 50.0 \\
10 & 100.0 & 100.0 & 100.0 & 100.0 & 58.3 & 100.0 \\
15 & 100.0 & 100.0 & 100.0 & 100.0 & 83.3 & 100.0 \\
20 & 100.0 & 100.0 & 100.0 & 100.0 & 100.0 & 100.0 \\
\hline
\end{tabular}

$\mathrm{RC}=$ Ruptured cyst; $\mathrm{DD}=$ Delayed development of germ cells; $\mathrm{PN}=$ Pyknotic nucleus; $\mathrm{CC}=$ Cell cluster; $\mathrm{DC}=$ Detachment of cyst wall; Va= Vacuolization.

re 2). In treatments exposed to concentrations higher than $3 \mathrm{mg} / \mathrm{L}$, the quantity of cells with pyknotic core was 91.67\% (Table 4). Yamaguchi et al. (2007), studying the effect of heavy metals in several species of fish, observed that the spermatogenesis process did not proceed beyond spermatogonia because it was interrupted by cell death. Dutta et al. (2003), studying the effect of pollutants in the reproduction of fish, reported the interruption of the proliferation phase in spermatogenesis of "bluegill" (Lepomis macrochirus).

There was an increase in cells with vacuolization (Figure 2), which are likely to become necrotic cells in a more advanced stage. In fish that were not exposed to $\mathrm{Zn}$, the vacuolization was not null, but the rate value was 

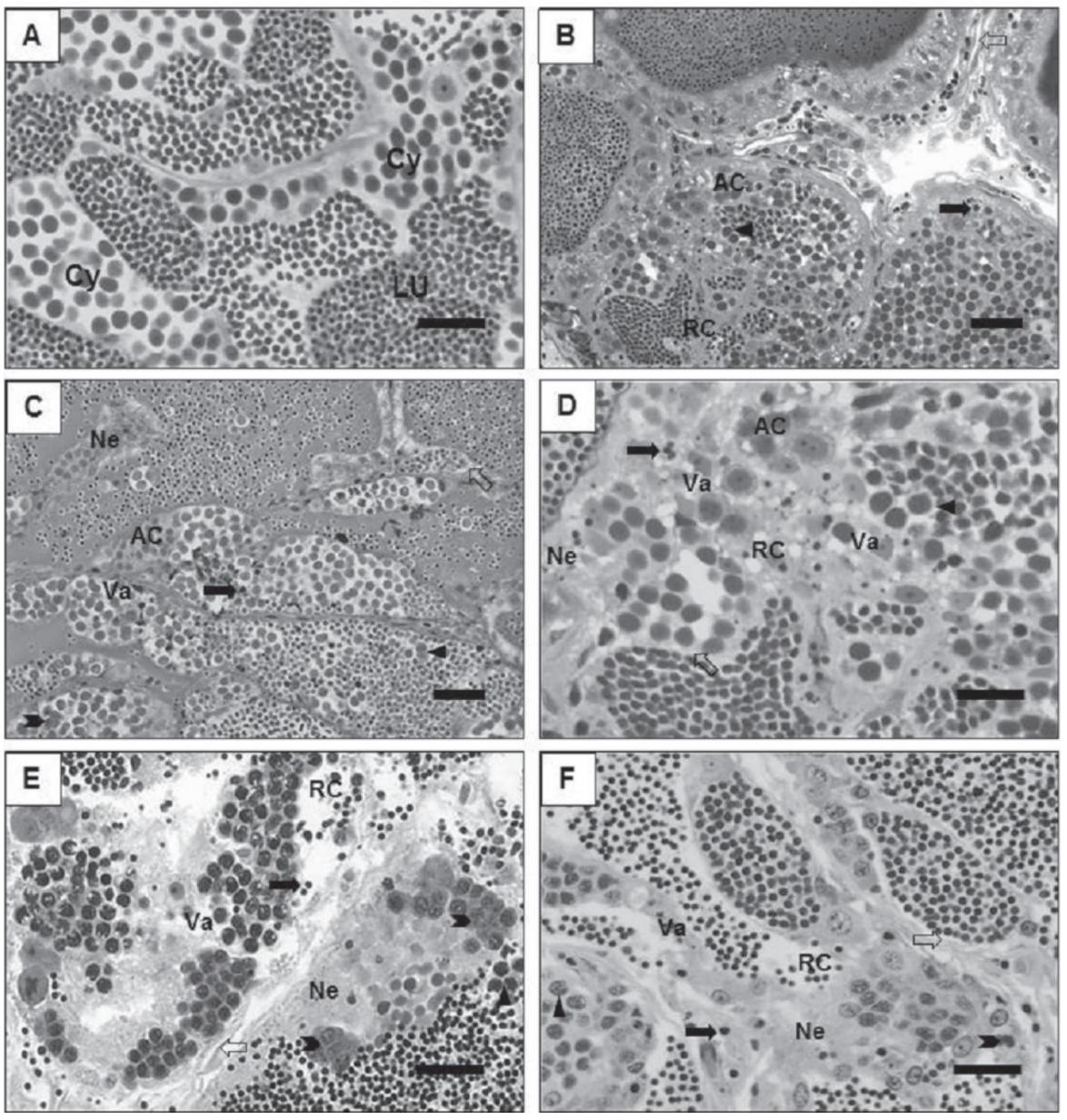

Figure 2. Testis of Astyanax aff. bimaculatus exposed to different concentrations of zinc. A) Control group. B) $3 \mathrm{mg} / \mathrm{L}$. C) $5 \mathrm{mg} / \mathrm{L}$. D) $10 \mathrm{mg} / \mathrm{L}$. E) $15 \mathrm{mg} / \mathrm{L}$. F) $20 \mathrm{mg} / \mathrm{L}$. Bar: $20 \mu \mathrm{m}$. Cy= Cyst; Lu= lumen; Ruptured cyst= RC; Delayed development of germ cells= arrowhead; Pyknotic nucleus = full arrow; Cell cluster= motto; Detachment of cyst wall = blank arrow; Vacuolization= Va.

considerably low, compared to the exposed animals, which reached total vacuolization when concentrations were equal to or higher than $10 \mathrm{mg} / \mathrm{L}$ (Table 4). Yamaguchi et al. (2007) studied the spermatogenesis in "sutchi catfish" (Pangasianodon hypophthalmus) exposed to molybdenum, and found necrotic areas in the testes.

The increase in $\mathrm{Zn}$ concentration caused the formation of clusters of germ cells (Figure 2C, E and F) due to the process of cell division, which was not normally completed (Table 2). Toxic substances seem to act indirectly on the balance among human chorionic gonadotropin, vitellogenic, dopamine and estrogen, which results in the differentiation, maturation, gonadal morphology and physiology, though it may have a direct influence on cell divisions of germ tissue (Adams, 1990).

It was also found a positive correlation between concentration and increase in the rupture and displacement of cysts, causing retraction in the seminiferous tubules, which was not observed in the animals in the control group (Table 3; Figure 2). There was no increase in the number of cysts in the different concentrations, compared to the control group (Table 5).

The production of sperm in groups submitted to treatments with 10,15 and $20 \mathrm{mg} / \mathrm{L}$ was reduced. On the other hand, production of tubular fluid in the seminiferous tubules of animals treated with 5,15 and $20 \mathrm{mg} / \mathrm{L}$ increased. The animals in the treatment with $10 \mathrm{mg} / \mathrm{L}$ presented no significant increase in tubular fluid because the number of cysts forming the tubule caused increased wall thickness and the consequent reduction in tubular lumen. This result might be due to the toxicity of $\mathrm{Zn}$, which possibly caused the apoptosis of germ cells, thus decreasing the quantity of viable sperm. There was no statistic difference in the tubule and intertubular ratio (Table 5).

The CONAMA (National Council of Environment in Brazil) resolution no. 357, dated 03/17/2005, sets the maximum value of $5 \mathrm{mg} / \mathrm{L}$ of $\mathrm{Zn}^{2+}$ for water proper for animal breeding (Conama, 2005), which is similar to the international agencies. However, according to this study, this concentration of $\mathrm{Zn}$ in the water compromised the physiological functions of liver and reproduction of the 
Table 5. Testicular constitution percentage in testes of Astyanax aff. bimaculatus submitted to different concentrations of zinc

\begin{tabular}{|c|c|c|c|c|c|}
\hline \multirow{3}{*}{$\begin{array}{l}\text { Zn concentration } \\
(\mathrm{mg} / \mathrm{L})\end{array}$} & \multirow{3}{*}{ Cyst } & \multicolumn{3}{|c|}{ Testicular constitution (\%) } & \multirow{3}{*}{ Tubule } \\
\hline & & \multicolumn{2}{|c|}{ Lumen } & \multirow{2}{*}{ Intertubular } & \\
\hline & & SP & TF & & \\
\hline 0 & $46.52^{\mathrm{ab}}$ & $34.14^{c}$ & $12.82^{\mathrm{a}}$ & $6.52^{\mathrm{a}}$ & $93.48^{\mathrm{a}}$ \\
\hline 3 & $46.25^{\mathrm{ab}}$ & $30.36^{\mathrm{bc}}$ & $18.98^{\mathrm{ab}}$ & $4.41^{\mathrm{a}}$ & $95.59^{\mathrm{a}}$ \\
\hline 5 & $37.05^{\mathrm{a}}$ & $33.45^{\mathrm{c}}$ & $25.64^{\mathrm{b}}$ & $3.86^{\mathrm{a}}$ & $96.14^{\mathrm{a}}$ \\
\hline 10 & $54.84^{\mathrm{b}}$ & $18.85^{\mathrm{ab}}$ & $21.94^{\mathrm{ab}}$ & $4.37^{\mathrm{a}}$ & $95.63^{\mathrm{a}}$ \\
\hline 15 & $48.53^{\mathrm{ab}}$ & $19.18^{\mathrm{ab}}$ & $27.23^{\mathrm{b}}$ & $5.06^{\mathrm{a}}$ & $94.94^{\mathrm{a}}$ \\
\hline 20 & $51.31^{\mathrm{ab}}$ & $13.39^{\mathrm{a}}$ & $28.77^{\mathrm{b}}$ & $6.53^{\mathrm{a}}$ & $93.47^{\mathrm{a}}$ \\
\hline $\mathrm{CV}(\%)$ & 29.25 & 43.52 & 37.59 & 52.67 & 2.85 \\
\hline
\end{tabular}

* Means with the same letter do not differ significantly $(\mathrm{p}>0.05) . \mathrm{SP}=$ Spermatozoon; $\mathrm{TF}=$ Tubular fluid.

species. The increased number of hepatocytes indicates a compensatory mechanism to restore homeostasis due to toxic effects of $\mathrm{Zn}$, and the delayed development of cysts led to a reduction in sperm production, which may compromise the fertility rate, and, thus, the maintenance of population stocks.

\section{CONCLUSIONS}

It was possible to estimate the $\mathrm{LC}_{50}$ after the acute exposure. The exposure to $\mathrm{Zn}$ caused histopathological changes in liver and testes. A. aff. bimaculatus proved to be a sensitive species, even when exposed to low concentrations and it can be considered as bioindicator.

\section{REFERENCES}

Adams SM (1990) Biological indicators of stress in fish. American Fisheries Society Symposium, 8:190-199.

Celik U \& Oehlenschlager J (2004) Determination of zinc and copper in fish samples collected from Northeast Atlantic by DPSAV. Food Chemistry, 87:343-347.

Conama - Conselho Nacional do Meio Ambiente (2005) Resolução $\mathrm{n}^{\circ} 357$ de 17/03/2005. Dispõe sobre a classificação dos corpos de água e diretrizes ambientais para o seu enquadramento, bem como estabelece as condições e padrões de lançamento de efluentes, e dá outras providências. p.58-63.

De La Torre FR, Salibián A \& Ferrari L (2000) Biomarkers assessment in juvenile Cyprinus carpio exposed to waterborne cadmium. Environmental Pollution, 109:277-282.

Dutta HM \& Meijerb HJM (2003) Sublethal effects of diazinon on the structure of the testis of bluegill, Lepomis macrochirus: a microscopic analysis. Environmental Pollution, 125:355-360.

Dutta HM, Adhikari S, Singh NK, Roy PK \& Munshi JSD (1993) Histopathological changes induced by Malathion in the liver of freshwater catfish Heteropneustes fossilis (Bloch). Bulletin of Environmental Contamination and Toxicology, 51:895-900.

Fishbase (2013) Astyanax bimaculatus. Available in: <http:// www.fishbase.org/summary/Astyanax-bimaculatus.html>. Acessed on: April, $6^{\text {th }}, 2013$

Fujimoto RY, Cruz C \& Moraes FR (2008) Análise de efluente e histologia da pele, fígado e rim de pacus (Piaractus mesopotamicus) suplementados com cromo trivalente. Boletim do Instituto de Pesca, $34: 117-124$
Gül S, Belge-Kurutas E, Yildiz E, Sahan A \& Doran F (2004) Pollution correlated modifications of liver antioxidant systems and histopathology of fish (Cyprinidae) living in Seyhan Dam Lake, Turkey. Environment International, 30:605-609.

Hogstrand C \& Wood CM (1995) Mechanisms for zinc acclimation in freshwater rainbow trout. Marine Environmental Research, 39:131-135.

Martinez CBR \& Cólus IMS (2002) Biomarcadores em peixes neotropicais para o monitoramento da poluição aquática na bacia do rio Tibagi. In: Medri ME, Bianchini E, Shibatta AO \& Pimenta JÁ (Eds.) A bacia do rio Tibagi. Londrina, Universidade Estadual de Londrina. p.551-577.

Matta SLP, Vilela DAR, Godinho HP \& França LR (2002) The goitrogen 6-n-propyl-2-thiouracil (PTU) given during testis development increases Sertoli and germ cell number per cyst in fish: The tilapia (Oreochromis niloticus) model. Endocrinology, 143:970-978.

McGeer JC, Szebedinszky C, McDonald DG \& Wood CM (2000) Effects of chronic sublethal exposure to waterborne $\mathrm{Cu}, \mathrm{Cd}$ or $\mathrm{Zn}$ in rainbow trout 1: Iono-regulatory disturbance and metabolic costs. Aquatic Toxicology, 50:231-243.

Montoya LNF (2008) Efeitos do thiodan ${ }^{\circledR}$ sobre a morfologia do testículo de tilápia nilótica (Oreochromis niloticus) sexualmente imatura. Dissertação de Mestrado. Universidade Federal de Viçosa, Viçosa. 76p.

Munteanu V \& Munteanu G (2007) Biomonitoring of mercury pollution: A case study from the Dniester River. Ecological Indicators, 7:489-496

Nigro M, Falleni A, Del Barga I, Scarcelli V, Lucchesi P, Regoli F \& Frenzilli G (2006) Cellular biomarkers for monitoring estuarine environments: Transplanted versus native mussels. Aquatic Toxicology, 77:339-347.

Oliveira Ribeiro CA, Belger L, Pelletier É \& Rouleau C (2002) Histopathological evidence of inorganic mercury and methyl mercury toxicity in the artic charr (Salvelinus alpinus). Environmental Research, 90:217-225.

Oliveira Ribeiro CA, Vollaire Y, Sanchez-Chardi A \& Roche H (2005) Bioaccumulation and the effects of organochlorine pesticides, $\mathrm{PAH}$ and heavy metals in the Eel (Anguilla anguilla) at the Camargue Nature Reserve, France. Aquatic Toxicology, 74:53-69.

Pacheco M \& Santos MA (2002) Biotransformation, genotoxic, and histopathological effects of environmental contaminants in European eel (Anguilla anguilla L.). Ecotoxicology and Environmental Safety, 53:331-347.

Papagiannis I, Kagalou I, Leonardos J, Petridis D \& Kalfakakou V (2004) Copper and zinc in four freshwater fish species from Lake Pamvotis (Greece). Environment International, 30:357-362. 
Rabitto IS, Alves Costa JRM, Silva de Assis HC, Pelletier É, Akaishi FM, Anjos A, Randi MAF \& Oliveira Ribeiro CA (2005) Effects of dietary $\mathrm{Pb}$ (II) and tributyltin on neotropical fish, Hoplias malabaricus: histopathological and biochemical findings. Ecotoxicology and Environmental Safety, 60:147-156.

Rand GM \& Petrocelli SR (1985) Fundamentals of aquatic toxicology: methods and applications. Washington, Hemisphere Publishing Corporation. 666p.

Roberts RJ (1989) Fish pathology. $2^{\mathrm{a}}$ ed. London, Braillière Tindall. $467 \mathrm{p}$.

Rodrigues EL \& Fanta E (1998) Liver histopathology of the fish Brachydanio rerio Hamilton-Buchman after acute exposure to sublethal levels of the organophosphate Dimethoate 500. Revista Brasileira de Zoologia, 15:441-450.

Romani R, Antognelli C, Baldracchini F, De Santis A, Isani G, Giovannini E \& Rosi G (2003) Increased acetylcholinesterase activities in specimens of Sparus auratus exposed to sublethal copper concentrations. Chemico-Biological Interactions, 145:321-329.

Ross LG \& Ross B (2000) Book reviews: anaesthetic and sedative techiniques for aquatic animals. Journal of Fish Biology, 56:15621565.

Santos AA, Ranzani-Paiva MJT, Felizardo NN \& Rodrigues EL (2004) Análise histopatológica de fígado de tilápia-do-Nilo, Oreochromis niloticus, criada em tanque-rede na Represa de Guarapiranga, São Paulo, SP, Brasil. Boletim do Instituto de Pesca, 30:141-145.
Santos DCM, Matta SLP, Dergam JA \& Oliveira JA (2012) Histological alterations in gills of Astyanax aff. bimaculatus caused by acute exposition to zinc. Experimental and Toxicologic Pathology, 64:861866.

Souza VL, Lunardi LO, Vasques LH, Casaletti L, Nakaghi LSO \& Urbinati EC (2001) Morphometric alterations in hepatocytes and ultrastructural distribution of liver glycogen in pacu (Piaractus mesopotamicus Holmberg, 1887) during food restriction an refeeding. Brazilian Journal of Morphological Sciences, 18:15-20.

Stentiford GD, Longshaw M, Lyons BP, Jones G, Green M \& Feist SW (2003) Histopathological biomarkers in estuarine fish species for the assessment of biological effects of contaminants. Marine Environmental Research, 55:137-159.

Verlag GF (1982) An atlas of fish histology: normal and pathological features. Tokyo, Kodansha. 147p.

Wester PW, Van Der Ven LTM, Vethaak AD, Grinwis GCM \& Vos JG (2002) Aquatic toxicology: opportunities for enhancement through histopathology. Environmental Toxicology and Pharmacology, 11:289295.

Yamaguchi S, Miura C, Ito A, Agusa T, Iwata H, Tanabe S, Tuyen BC \& Miura T (2007) Effects of lead, molybdenum, rubidium, arsenic and organochlorines on spermatogenesis in fish: Monitoring at Mekong Delta area and in vitro experiment. Aquatic Toxicology, 83:43-51. 